\title{
Effects of Replacing Grass Silage with Barley Silage in Dairy Cow Diets
}

\author{
S. Ahvenjärvi, ${ }^{\star 1}$ E. Joki-Tokola, $\dagger$ A. Vanhatalo, ${ }^{2}$ S. Jaakkola, ${ }^{\star}$ and P. Huhtanen* \\ *MTT Agrifood Research Finland, Animal Production Research, Animal Nutrition, 31600 Jokioinen, Finland \\ †MTT Agrifood Research Finland, North Ostrobothnia Research Station, Tutkimusasemantie 15, 92400 Ruukki, Finland
}

\section{ABSTRACT}

This study examined the effects of gradually replacing grass silage with whole-crop barley silage on feed intake, ruminal and total tract digestibility, and milk yield in lactating dairy cows. Four dairy cows in early lactation, equipped with rumen cannulas, were fed 4 diets over four 21-d periods. The diets consisted of 4 forage mixtures of grass silage and whole-crop barley silage supplemented with $8.9 \mathrm{~kg} / \mathrm{d}$ of concentrates [dry matter (DM) basis]. The proportion of barley silage in the forage was adjusted to $0,0.20,0.40$, and $0.60 \mathrm{~kg} /$ $\mathrm{kg}$ of DM. Ruminal nutrient metabolism was measured on the basis of digesta flow entering the omasal canal. Ammonia concentrations and volatile fatty acid profiles were determined in the rumen fluid. Ruminal digestion and passage kinetics were assessed by the rumen evacuation technique. Replacement of grass silage with barley silage had no effect on DM, digestible organic matter, or neutral detergent fiber (NDF) intake, but starch intake increased, whereas nitrogen and digestible NDF (dNDF) intake decreased. Increases in the proportion of barley silage linearly decreased milk yield, and the molar proportion of acetate in the rumen, and increased that of propionate, butyrate, and valerate. Decreases in milk yield due to inclusion of barley silage were attributed to decreases in diet digestibility and nutrient supply to the animal. Barley silage linearly decreased organic matter digestibility in the total tract and NDF and dNDF digestibility in the rumen and the total tract, and decreased nonammonia $\mathrm{N}$ flow entering the omasal canal. No significant differences between diets were noted in the digestion rate of $\mathrm{dNDF}$ or passage rate of indigestible NDF from the rumen. Decreases in organic matter and NDF digestibility were attributed to the higher indigestible NDF concentration of barley silage compared with that of grass silage and to the smaller pool size of $d N D F$ in the rumen.

Received August 29, 2005.

Accepted November 17, 2005.

${ }^{1}$ Corresponding author: seppo.ahvenjarvi@mtt.fi

${ }^{2}$ Present address: Department of Animal Science, P.O. Box 28, 00014 University of Helsinki, Finland.
Key words: dairy cow, digestibility, whole-crop barley silage

\section{INTRODUCTION}

Small grain cereals are widely grown for animal feed in temperate climates. Often, only the grain crop is utilized to increase the energy concentration of diets for high-producing animals such as lactating dairy cows. Use of the whole crop considerably increases the total harvestable DM yield because straw (stem and leaves) constitutes approximately one-half of the total yield (Kennelly and Weinberg, 2003). The digestibility of whole-crop cereals is highly dependent on the proportion of straw and is often lower than that of good quality grass silage (Sutton et al., 1997, 1998; Abdalla et al., 1999). However, the lower digestibility is largely compensated for by higher DMI such that energy intake is maintained (Phipps et al., 1995; Abdalla et al., 1999; Sinclair et al., 2003). Several studies have demonstrated that a partial replacement of grass silage with whole-crop cereals may not have adverse effects on milk production in dairy cows (Phipps et al., 1995; Abdalla et al., 1999; Sinclair et al., 2003).

In Finland, barley is the dominant small-grain species utilized for whole-crop production. According to current practices, the crop is harvested at the dough stage with a DM concentration of between 30 and $40 \%$. Within such a range of DM content, active fermentation during the ensiling process is likely to occur, and therefore the preservation of barley silage is based on fermentation using acid-based additives to ensure good fermentation quality (Vanhatalo et al., 1999).

The underlying hypothesis of the current study was that incorporation of increasing amounts of whole-crop barley into dairy cow diets might compromise the intake of digestible nutrients and milk production. The objective was to quantify the effects of gradually replacing grass silage with whole-crop barley on diet DMI, digestibility, ruminal nutrient metabolism, and milk yield in lactating dairy cows.

\section{MATERIALS AND METHODS}

\section{Animals and Diets}

The effects of replacing grass silage with whole-crop barley silage in dairy cow diets were studied with 4 
Table 1. Chemical composition of grass silage, whole-crop barley silage, and concentrates

\begin{tabular}{|c|c|c|c|}
\hline Item & $\begin{array}{l}\text { Grass } \\
\text { silage }^{1}\end{array}$ & $\begin{array}{l}\text { Whole- } \\
\text { crop } \\
\text { barley } \\
\text { silage }^{2}\end{array}$ & Concentrates \\
\hline $\mathrm{DM}, \mathrm{g} / \mathrm{kg}$ & 218 & 311 & 888 \\
\hline \multicolumn{4}{|l|}{ Composition, $\mathrm{g} / \mathrm{kg}$ of DM } \\
\hline Ash & 76 & 75 & 76 \\
\hline $\mathrm{N}$ & 22.2 & 15.8 & 25.6 \\
\hline Starch & 1 & 124 & 357 \\
\hline Water-soluble carbohydrates & 30 & 26 & $\mathrm{NA}^{5}$ \\
\hline NDF & 597 & 488 & 276 \\
\hline $\mathrm{iNDF}^{3}$ & 97 & 184 & 90 \\
\hline $\mathrm{dNDF},{ }^{4} \mathrm{~g} / \mathrm{kg}$ of $\mathrm{NDF}$ & 838 & 626 & 674 \\
\hline
\end{tabular}

${ }^{1}$ Fermentation quality: $\mathrm{pH} 3.9$; In DM, g/kg: lactic acid 50, acetic acid 21, propionic acid 0.0 , butyric acid 1.3, ethanol 7.7; In total $\mathrm{N}$, g/kg: soluble N 636, ammonia-N 47.

${ }^{2}$ Fermentation quality: $\mathrm{pH} 3.7$; In DM, g/kg: lactic acid 56 , acetic acid 22 , propionic acid 0.0 , butyric acid 0.2 , ethanol 9.6; In total $\mathrm{N}$, $\mathrm{g} / \mathrm{kg}$ : soluble N 705, ammonia-N 62.

${ }^{3} \mathrm{iNDF}=$ Indigestible NDF; determined by 12 -d in situ incubation in the rumen.

${ }^{4} \mathrm{dNDF}=$ Digestible NDF.

${ }^{5} \mathrm{NA}=$ Not analyzed.

multiparous Ayrshire dairy cows equipped with rumen cannulas (Bar Diamond, Inc., Parma, ID). The cows weighed $606 \mathrm{~kg}(\mathrm{SD}=75)$ and were $57 \mathrm{~d}(\mathrm{SD}=3.6)$ postpartum at the beginning of the study. The study consisted of 4 diets offered to each animal according to a $4 \times 4$ Latin square design. Each period was $21 \mathrm{~d}$, with an adaptation period from d 1 to 13 followed by a sampling period from d 14 to 21 .

The diets were based on grass silage that was gradually replaced with (proportionally $0.20,0.40$, and 0.60 of DM) whole-crop barley silage (Table 1). Cows were offered silage ad libitum, allowing 5 to $10 \%$ for refusals. Diets were supplemented with $8.9 \mathrm{~kg}$ of DM/d of a concentrate mixture consisting of $307,307,154,200,20$, 8 , and $3 \mathrm{~g} / \mathrm{kg}$ of barley, oats, molassed sugar beet pulp, solvent-extracted rapeseed meal, a commercial mixture of vitamins and minerals, calcium, and $\mathrm{NaCl}$, respectively. The concentrate was offered twice daily at 0600 and $1800 \mathrm{~h}$. Grass silage was prepared from a primary growth of mixed timothy (Phleum pratense) and meadow fescue (Festuca pratensis) grass that was cut using a mower conditioner, wilted for $6 \mathrm{~h}$, and then harvested using a precision-chop forage harvester. Grass was ensiled in a bunker silo using a formic acidbased additive (AIV-10, Kemira Chemicals Ltd., Helsinki, Finland), which was applied at a rate of $4.8 \mathrm{~L} / \mathrm{t}$ at harvest. Whole-crop barley was harvested $82 \mathrm{~d}$ after sowing and $27 \mathrm{~d}$ after the start of heading at the early dough stage using a direct-cut flail harvester. It was then ensiled in a bunker silo using the same additive applied at a rate of $5.2 \mathrm{~L} / \mathrm{t}$ at harvest. Mixtures of grass silage and whole-crop barley silage were prepared in a mixer wagon.

Cows were milked twice daily at 0700 and $1700 \mathrm{~h}$. Milk yield was recorded daily, but only the yield recorded on d 15 to 21 is reported in the current paper. Milk samples were obtained from 4 consecutive milkings on d 18 to 20 and analyzed for fat, protein, and lactose. Silage samples were collected daily on $\mathrm{d} 15$ to 20 , stored frozen at $-20^{\circ} \mathrm{C}$ until the end of each period, and then submitted for determination of DM and chemical composition. Each period's concentrate mixture was sampled and chemically analyzed.

\section{Marker Administration}

To determine digesta flow entering the omasal canal, 3 external markers (Cr-straw, LiCoEDTA, and Yb-chloride) were administered into the rumen via rumen cannulas. Coarsely chopped barley straw was mordanted with $\mathrm{Cr}$ according to the method described by Udén et al. (1980). To facilitate rapid equilibration of the marker concentration in the rumen, a priming dose of $\mathrm{Cr}$ straw ( $4.5 \mathrm{~g}$ of $\mathrm{Cr}$ ) was given at $0600 \mathrm{~h}$ on $\mathrm{d} 16$. Thereafter, $\mathrm{Cr}$ was administered twice daily at 0600 and $1800 \mathrm{~h}$ $(3.6 \mathrm{~g}$ of $\mathrm{Cr} / \mathrm{d})$ until the end of each period. On $\mathrm{d} 17$ at $0600 \mathrm{~h}$, a priming dose of LiCoEDTA (2.4 g of Co) and Yb-chloride (2.5 g of $\mathrm{Yb}$ ) was administered directly into the rumen via rumen cannulas. After the priming dose, a continuous infusion consisting of LiCoEDTA (1.6 g of $\mathrm{Co} / \mathrm{d})$ and $\mathrm{Yb}$-chloride (1.7 $\mathrm{g}$ of $\mathrm{Yb} / \mathrm{d})$, dissolved in $6 \mathrm{~L}$ of distilled water, was administered until the end of each period using a peristaltic pump (Watson-Marlow 502 S, Falmouth, UK).

\section{Digesta Sampling}

To assess ruminal fermentation, liquid samples were obtained on $\mathrm{d} 14$ immediately before the morning meal and $1,2,3,4,6,8$, and $10 \mathrm{~h}$ after the meal via the rumen cannula using a perforated plastic tube. Ruminal samples were strained immediately through one layer of cheesecloth and measured for $\mathrm{pH}$. For VFA analysis, $0.5 \mathrm{~mL}$ of saturated $\mathrm{HgCl}_{2}$ solution and 2.0 $\mathrm{mL}$ of $1 M \mathrm{NaOH}$ solution were added to $5.0 \mathrm{~mL}$ of rumen fluid. For ammonia $\mathrm{N}$ analysis, $0.3 \mathrm{~mL}$ of $50 \%$ $\mathrm{H}_{2} \mathrm{SO}_{4}$ was added to $15 \mathrm{~mL}$ of rumen fluid. Samples of rumen fluid were subsequently stored at $-20^{\circ} \mathrm{C}$. To determine rumen pool size, ruminal contents were manually evacuated on d 15 at $0900 \mathrm{~h}$ into two 60-L barrels kept warm in a water bath. Rumen contents were mixed by hand, and a subsample was taken for analysis of DM content and chemical composition.

To determine the composition of bacteria leaving the rumen, $400 \mathrm{~mL}$ of digesta were collected from the oma- 
sal canal on d 18 immediately before the morning meal, and 4 and $8 \mathrm{~h}$ afterwards. The samples were chilled in an ice bath until the bacteria were harvested using a differential centrifugation technique. Samples were first centrifuged at $200 \times g$ for $7 \mathrm{~min}$, and the supernatant was filtered through 2 layers of cheesecloth. The pellet was then suspended in $200 \mathrm{~mL}$ of saline, and homogenized with a blender for $30 \mathrm{~s}$ to detach solidsassociated bacteria. This suspension was further centrifuged at $200 \times g$ for $7 \mathrm{~min}$. The supernatant was filtered through 2 layers of cheesecloth and pooled with the supernatant from the first centrifugation. The filtered supernatant was centrifuged again at $200 \times g$ for $7 \mathrm{~min}$. Following centrifugation, the supernatant was removed by aspiration, and centrifuged at $10,000 \times g$ for $30 \mathrm{~min}$ to sediment bacteria. The bacterial pellet was suspended in distilled water and lyophilized.

To determine ruminal digestibility, digesta samples were obtained from the omasal canal using a sampling technique similar to that described by Huhtanen et al. (1997), incorporating 3 modifications: i) a larger sampling tube was used (14 vs. $9.5 \mathrm{~mm}$ i.d.), ii) solenoid valves were used to control the vacuum and pressure phases in the system, and iii) the sampling device was secured in the omasal canal using a 500-g weight inserted into the abomasum instead of a compressible ring inserted into the omasal canal. Omasal canal samples of $400 \mathrm{~mL}$ were collected on d 19 at 1, 4, 7, and 9 $\mathrm{h}$ after the morning meal. On d 20 to 21, the sampling time advanced $1 \mathrm{~h}$ each day, such that samples represented each hour between the morning and evening meals. Although digesta flow from the rumen may exhibit substantial diurnal variation (Gill et al., 1999), sampling over $12 \mathrm{~h}$ in combination with the use of several flow markers was considered to ensure accurate flow measurements. Samples were frozen immediately after sampling, stored at $-20^{\circ} \mathrm{C}$ until thawed, and fractionated into 3 phases as follows. Whole digesta were first squeezed through one layer of cheesecloth. Particulate matter retained on the cheesecloth was defined as the large-particle phase. The filtrate was separated into small-particle and fluid phases by centrifugation at $10,000 \times g$ for $15 \mathrm{~min}$ and removing the supernatant by aspiration. All digesta phases were frozen at $-20^{\circ} \mathrm{C}$ and lyophilized for chemical analysis. Total tract digestibility was determined by collection of feces on d 19 to 21 . Daily $\mathrm{N}$ excretion in urine was determined by collecting urine using a light harness attached around the vulva with an adhesive and draining the urine into a container with a flexible tube. Urine $\mathrm{pH}$ was maintained below 3 using $10 \mathrm{~N} \mathrm{H}_{2} \mathrm{SO}_{4}$.

Digesta flow entering the omasal canal was calculated using a triple marker method as described by France and Siddons (1986) based on the use of Co and
$\mathrm{Yb}$ as liquid and small-particle phase markers, respectively, and $\mathrm{Cr}$ and indigestible NDF (iNDF) as largeparticle phase markers. True digesta flow was calculated as the mean of the results obtained using 2 different triple-marker combinations, $\mathrm{Co} / \mathrm{Yb} / \mathrm{Cr}$ and $\mathrm{Co} / \mathrm{Yb} /$ iNDF. Digesta flows were consistent based on both marker combinations, but using the mean values instead of either combination alone was assumed to improve the accuracy of flow measurements (Ahvenjärvi et al., 2001). Microbial $\mathrm{N}$ flow was determined using purine bases as microbial marker. For calculation of the amount of OM truly digested in the rumen, microbial OM flow entering the omasal canal was calculated based on N:OM ratio determined in bacterial samples (mean 0.08, SD 0.008, $\mathrm{n}=16$ ).

\section{Chemical Analysis}

The DM content of feed ingredients and feces were determined after these were kept for $18 \mathrm{~h}$ in a forcedair oven at $105^{\circ} \mathrm{C}$. Silage DM content was corrected for volatile losses according to Huida et al. (1986). For chemical analysis, feed ingredients and feces were dried to a constant weight at $60^{\circ} \mathrm{C}$ in a forced-air oven, and ground using a 1-mm screen. The DM concentration of air-equilibrated samples was determined after these were kept for $16 \mathrm{~h}$ at $105^{\circ} \mathrm{C}$. Ash was determined after ignition in a muffle furnace at $600^{\circ} \mathrm{C}$ for $18 \mathrm{~h}$. Nitrogen concentration in fresh samples of silage, feces, and urine was determined by the Kjeldahl method using $\mathrm{CuSO}_{4}$ as a catalyst. Nitrogen concentration in dry samples was determined using a Dumas-type $\mathrm{N}$ analyzer (Leco FP-428; Leco Corporation, St. Joseph, MI). Starch was determined in feed ingredients, reconstituted omasal canal digesta, and feces as described by Bach Knudsen et al. (1987). The NDF concentration was determined in the presence of $\mathrm{Na}_{2} \mathrm{SO}_{3}$ according to Van Soest et al. (1991). Ammonia $\mathrm{N}$ concentration in rumen fluid and reconstituted omasal canal digesta was determined using a colorimetric method described by McCullough (1967). Volatile fatty acids were analyzed in rumen fluid by gas chromatography as described by Huhtanen et al. (1998). Purine bases in rumen bacteria and omasal canal digesta were determined as described by Zinn and Owens (1986). Digesta and feces were analyzed for $\mathrm{Co}, \mathrm{Yb}$, and $\mathrm{Cr}$ according to Williams et al. (1962). To determine iNDF concentration in feed ingredients, feces, large-particle, and small-particle phases, samples were incubated in duplicate for $12 \mathrm{~d}$ in the rumens of 2 cows using $17-\mu \mathrm{m}$ polyester bags (Sefar Inc., Ruschlikon, Switzerland). After rumen incubation, the bags were rinsed with cold water using a household washing machine, dried to a constant weight at $60^{\circ} \mathrm{C}$, boiled in $\mathrm{NDF}$ solution, rinsed, and dried to a constant weight. 
Table 2. Effect of replacing grass silage by whole-crop barley silage on DM intake and milk production

\begin{tabular}{|c|c|c|c|c|c|c|c|}
\hline \multirow[b]{2}{*}{ Item } & \multicolumn{4}{|c|}{ Proportion of barley silage ${ }^{1}$} & \multirow[b]{2}{*}{$\mathrm{SEM}^{2}$} & \multicolumn{2}{|c|}{$\begin{array}{l}\text { Orthogonal } \\
\text { contrasts }\end{array}$} \\
\hline & 0 & 20 & 40 & 60 & & Linear & Quadratic \\
\hline \multicolumn{8}{|l|}{ DM intake, kg/d } \\
\hline Silage & 12.09 & 12.06 & 12.72 & 11.83 & 0.506 & 0.96 & 0.46 \\
\hline Concentrates & 8.88 & 8.69 & 8.88 & 8.94 & 0.094 & 0.48 & 0.29 \\
\hline Total & 20.97 & 20.75 & 21.60 & 20.76 & 0.500 & 0.93 & 0.59 \\
\hline Digestible OM intake, $\mathrm{kg} / \mathrm{d}$ & 13.67 & 13.47 & 13.88 & 13.15 & 0.391 & 0.59 & 0.56 \\
\hline Milk, kg/d & 33.2 & 32.2 & 31.4 & 30.9 & 0.47 & 0.02 & 0.67 \\
\hline $\mathrm{FCM}, \mathrm{kg} / \mathrm{d}^{3}$ & 33.1 & 33.2 & 32.8 & 31.0 & 0.11 & $<0.01$ & $<0.01$ \\
\hline \multicolumn{8}{|l|}{ Milk composition, \% } \\
\hline Fat & 4.01 & 4.21 & 4.27 & 4.07 & 0.106 & 0.67 & 0.15 \\
\hline Protein & 3.06 & 3.02 & 3.11 & 3.05 & 0.031 & 0.65 & 0.77 \\
\hline Lactose & 4.93 & 4.94 & 4.99 & 4.97 & 0.026 & 0.24 & 0.72 \\
\hline \multicolumn{8}{|l|}{ Yield of milk components, $\mathrm{kg} / \mathrm{d}$} \\
\hline Fat & 1.32 & 1.36 & 1.35 & 1.24 & 0.017 & 0.04 & 0.01 \\
\hline Protein & 1.004 & 0.966 & 0.977 & 0.936 & 0.0160 & 0.07 & 0.93 \\
\hline Lactose & 1.63 & 1.58 & 1.57 & 1.53 & 0.018 & 0.02 & 0.81 \\
\hline
\end{tabular}

${ }^{1}$ Diets consisted of grass silage alone or with $0.20,0.40$, or 0.60 of this replaced by whole crop barley silage (on DM basis).

${ }^{2}$ For the diet of which 0.60 consisted of whole crop barley silage, SEM should be multiplied by 1.29.

${ }^{3} 4 \%$ FCM (NRC, 2001).

Finally, the residue was ignited at $600^{\circ} \mathrm{C}$ for $18 \mathrm{~h}$ to determine the indigestible ash-free NDF. Milk samples were analyzed for protein, fat, and lactose according to IDF International standard 141C:2000 using an infrared milk analyzer (MilkoScan 133B; Foss Electric, Hillerød, Denmark).

\section{Statistical Analyses}

Although repeated measurements of rumen fermentation parameters were taken, only mean values are currently reported. The effect of replacing grass silage with whole-crop barley silage on feed intake, digesta flow, diet digestibility, and ruminal fermentation was assessed using the following statistical model with the MIXED procedure of SAS (Littell et al., 1998):

$$
\mathrm{Y}_{\mathrm{ijk}}=\mu+\mathrm{A}_{\mathrm{i}}+\mathrm{P}_{\mathrm{j}}+\mathrm{D}_{\mathrm{k}}+\mathrm{e}_{\mathrm{ijk}}
$$

where A, P, and D are the fixed effects of animal, period, and diet, respectively. Sums of squares were further divided into orthogonal contrasts to assess the linear and quadratic effect of whole-crop barley silage inclusion.

\section{RESULTS}

\section{DMI and Milk Yield}

Both silages were restrictively fermented and of good quality in terms of low concentrations of fermentation acids, ammonium-N, butyric acid, and low $\mathrm{pH}$ (Table 1). Barley silage had a higher DM concentration than grass silage, but its concentrations of $\mathrm{N}, \mathrm{NDF}$, and digestible NDF (dNDF, g/kg of DM) were lower. The replacement of grass silage with barley silage had no effect on DMI or digestible OM intake (Table 2), but it altered the chemical composition of the diet. An increase in the proportion of barley silage from 0 to 0.60 decreased the $\mathrm{N}$ concentration in a linear manner from 23.7 to $21.4 \mathrm{~g} / \mathrm{kg}$ of $\mathrm{DM}$ and the NDF concentration from 440 to $407 \mathrm{~g} / \mathrm{kg}$ of DM, and increased the starch concentration from 153 to $200 \mathrm{~g} / \mathrm{kg}$ of DM. These changes in diet composition were associated with concomitant linear increases in starch intake and decreases in $\mathrm{N}$ intake. Intake of NDF was similar for the diets with the exception of the highest level of barley silage inclusion, whereas that of dNDF decreased as the inclusion rate of barley silage increased.

Increasing the proportion of barley silage resulted in linear decreases in milk yield, whereas the fat-corrected milk yield decreased in a quadratic manner, such that the largest difference was noted between the highest levels of barley silage inclusion (Table 2). Milk composition was not affected by the diet, but increases in the proportion of barley silage decreased milk fat yield in a quadratic manner, such that the fat yield was lowest at the highest barley silage inclusion level (0.60).

\section{Rumen Fermentation}

Replacement of grass silage with barley silage had a pronounced effect on the rumen fermentation pattern (Table 3). Increases in the proportion of barley silage linearly decreased the molar proportion of acetate and 
Table 3. Effect of replacing grass silage by whole-crop barley silage on rumen fermentation characteristics

\begin{tabular}{|c|c|c|c|c|c|c|c|}
\hline \multirow[b]{2}{*}{ Item } & \multicolumn{4}{|c|}{ Proportion of barley silage $^{1}$} & \multirow[b]{2}{*}{ SEM } & \multicolumn{2}{|c|}{$\begin{array}{l}\text { Orthogonal } \\
\text { contrasts }\end{array}$} \\
\hline & 0 & 20 & 40 & 60 & & Linear & Quadratic \\
\hline $\mathrm{pH}$ & 6.41 & 6.38 & 6.42 & 6.45 & 0.020 & 0.18 & 0.15 \\
\hline $\mathrm{NH}_{3}-\mathrm{N}, \mathrm{mmol} / \mathrm{L}$ & 5.59 & 5.86 & 4.87 & 4.69 & 0.386 & 0.08 & 0.59 \\
\hline Total VFA, mmol/L & 105 & 109 & 107 & 106 & 1.5 & 0.86 & 0.10 \\
\hline Molar proportion of VFA, $\mathrm{mmol} / \mathrm{mol}$ & & & & & & & \\
\hline Acetate & 661 & 639 & 637 & 622 & 3.3 & $<0.01$ & 0.33 \\
\hline Propionate & 170 & 178 & 178 & 191 & 3.1 & $<0.01$ & 0.40 \\
\hline Isobutyrate & 7.8 & 8.1 & 8.2 & 7.9 & 0.11 & 0.75 & 0.04 \\
\hline Butyrate & 128 & 140 & 141 & 142 & 2.0 & $<0.01$ & 0.04 \\
\hline Isovalerate & 12.0 & 12.3 & 12.5 & 12.6 & 0.46 & 0.38 & 0.95 \\
\hline Valerate & 13.2 & 14.7 & 14.7 & 15.5 & 0.28 & $<0.01$ & 0.35 \\
\hline Caproate & 7.7 & 8.1 & 9.1 & 8.7 & 0.39 & 0.07 & 0.33 \\
\hline$(\mathrm{Ac}+\mathrm{Bu}) / \mathrm{Pr}^{2}$ & 4.64 & 4.37 & 4.39 & 4.00 & 0.10 & $<0.01$ & 0.57 \\
\hline
\end{tabular}

${ }^{1}$ Diets consisted of grass silage alone or with $0.20,0.40$, or 0.60 of this replaced by whole crop barley silage (on DM basis).

${ }^{2}($ Acetate + butyrate) $/$ propionate.

increased that of propionate and valerate. The molar proportion of butyrate increased in a quadratic manner such that the difference was largest between the 2 lowest levels ( 0 and 0.20$)$. These changes were also reflected in a linear decrease in the ratio of acetate + butyrate to propionate. Barley silage decreased the mean ammonia-N concentrations $(P=0.08)$ in a linear manner, whereas the rumen $\mathrm{pH}$ and VFA concentrations were not affected by the diet.

\section{OM, Starch, and NDF Digestibility}

Increasing the inclusion rate of barley silage had no effect on the OM intake and ruminal digestibility, but total tract OM digestibility decreased linearly (Table 4). The effects on OM digestibility were attributed to lower NDF and dNDF digestibility in the rumen and total tract. In spite of linear decreases in dNDF intake, the flow of dNDF entering the omasal canal was not affected by the diet (data not shown, $P=0.74$ ). Increases in the level of barley silage tended decrease $(P=0.10)$ the proportion of dNDF digested in the rumen. Ruminal starch digestibility tended to increase $(P=0.06)$ in a quadratic manner, such that digestibility was lower for the grass silage diet than for the other diets. In contrast, starch was completely digested in the total tract digestibility independent of the diet.

\section{Nitrogen Metabolism}

Nitrogen intake decreased linearly with increasing inclusion of barley silage, which had a lower $\mathrm{N}$ concentration than grass silage (Table 5). Barley silage decreased NAN flow entering the omasal canal in a linear manner. The effects on total NAN flow were mainly due to the effects of barley silage on microbial $\mathrm{N}$ flow because the differences in nonmicrobial $\mathrm{N}$ flow were small. No differences between diets were noted in total NAN flow expressed as a fraction of $\mathrm{N}$ intake. On average across all diets, NAN flow was slightly higher than $\mathrm{N}$ intake, suggesting that microbial $\mathrm{N}$ synthesis exceeded feed protein degradation. Microbial efficiency and ruminal $\mathrm{N}$ degradability were not affected by the diet, whereas $\mathrm{N}$ digestibility in the total tract linearly decreased with increasing inclusion of barley silage. No diet effects on the amount of $\mathrm{N}$ excreted in feces was noted, but the amount of $\mathrm{N}$ excreted in urine linearly decreased with increasing barley silage.

\section{Rumen Pool Size and Passage Kinetics}

Replacement of grass silage with barley silage did not affect the amount of fresh digesta present in the rumen or the volume of ruminal digesta (Table 6). Rumen pool size of DM, OM, and NDF increased in a quadratic manner with increasing levels of barley silage. The pool sizes increased at barley silage inclusion levels from 0 to 0.40 and then decreased at the 0.60 level. Increases in the rate of barley silage inclusion resulted in concomitant linear increases in rumen pool size of iNDF, whereas rumen dNDF pool size decreased in a quadratic manner. The inclusion levels from 0 to 0.40 resulted in small linear decreases in dNDF pool size, but the decline was more profound between the levels 0.40 and 0.60 . No significant differences between the diets were noted in the passage rate of iNDF. Diet had no significant effect on the dNDF digestion rate, although there was a trend $(P=0.14)$ for a linear decrease with increasing levels of barley silage. Examination of the ratio of $\mathrm{dNDF}$ and iNDF concentrations in 
Table 4. Effect of replacing grass silage by whole-crop barley silage on OM, starch, NDF, and potentially digestible NDF intake and digestibility

\begin{tabular}{|c|c|c|c|c|c|c|c|}
\hline \multirow[b]{2}{*}{ Item } & \multicolumn{4}{|c|}{ Proportion of barley silage ${ }^{1}$} & \multirow[b]{2}{*}{$\mathrm{SEM}^{2}$} & \multicolumn{2}{|c|}{ Orthogonal contrasts } \\
\hline & 0 & 20 & 40 & 60 & & Linear & Quadratic \\
\hline \multicolumn{8}{|l|}{$\mathrm{OM}$} \\
\hline Intake, $\mathrm{kg} / \mathrm{d}$ & 19.42 & 19.23 & 20.04 & 19.27 & 0.469 & 0.89 & 0.60 \\
\hline \multicolumn{8}{|l|}{ Digestibility, kg/kg } \\
\hline In the rumen & 0.716 & 0.712 & 0.706 & 0.693 & 0.0098 & 0.20 & 0.69 \\
\hline Total tract & 0.703 & 0.701 & 0.693 & 0.683 & 0.0046 & 0.03 & 0.44 \\
\hline \multicolumn{8}{|l|}{ Starch } \\
\hline Intake, $\mathrm{kg} / \mathrm{d}$ & 3.18 & 3.44 & 3.88 & 4.18 & 0.073 & $<0.01$ & 0.85 \\
\hline \multicolumn{8}{|l|}{ Digestibility, kg/kg } \\
\hline In the rumen & 0.743 & 0.817 & 0.809 & 0.810 & 0.0187 & 0.10 & 0.13 \\
\hline Total tract & 0.992 & 0.992 & 0.996 & 0.997 & 0.0006 & $<0.01$ & 0.40 \\
\hline \multicolumn{8}{|l|}{ NDF } \\
\hline Intake, $\mathrm{kg} / \mathrm{d}$ & 9.25 & 9.01 & 9.12 & 8.43 & 0.283 & 0.17 & 0.48 \\
\hline \multicolumn{8}{|l|}{ Digestibility, kg/kg } \\
\hline In the rumen & 0.524 & 0.503 & 0.468 & 0.416 & 0.0119 & $<0.01$ & 0.29 \\
\hline Total tract & 0.575 & 0.557 & 0.522 & 0.487 & 0.0077 & $<0.01$ & 0.37 \\
\hline \multicolumn{8}{|l|}{$\mathrm{dNDF}^{3}$} \\
\hline Intake, $\mathrm{kg} / \mathrm{d}$ & 7.34 & 6.90 & 6.74 & 5.91 & 0.237 & 0.01 & 0.48 \\
\hline \multicolumn{8}{|l|}{ Digestibility, kg/kg } \\
\hline In the rumen & 0.666 & 0.656 & 0.629 & 0.582 & 0.0106 & $<0.01$ & 0.17 \\
\hline Total tract & 0.731 & 0.727 & 0.702 & 0.681 & 0.0052 & $<0.01$ & 0.18 \\
\hline Rumen/total tract & 0.910 & 0.902 & 0.896 & 0.857 & 0.0164 & 0.10 & 0.42 \\
\hline
\end{tabular}

${ }^{1}$ Diets consisted of grass silage alone or with $0.20,0.40$, or 0.60 of this replaced by whole-crop barley silage (on DM basis).

${ }^{2}$ For the diet of which 0.60 consisted of whole crop barley silage, SEM should be multiplied by 1.29.

${ }^{3} \mathrm{dNDF}=$ Digestible NDF.

the rumen and omasal canal illustrates the effects of barley silage on the passage kinetics of particulate matter. The ratio decreased in a linear manner in the rumen and omasal canal with increasing levels of barley silage, but the differences between diets were considerably smaller in the omasal canal than in the rumen. Furthermore, the difference between the rumen and omasal canal decreased with increasing levels of barley silage.

\section{DISCUSSION}

Examination of the chemical composition of grass and barley silage shows 2 distinct differences between the roughages. The major chemical component of grass silage is fiber that is more digestible than that of barley silage. The poor digestibility of barley silage fiber is compensated by a higher concentration of nonfiber car-

Table 5. Effect of replacing grass silage by whole-crop barley silage on $\mathrm{N}$ intake and ruminal and total tract digestibility

\begin{tabular}{|c|c|c|c|c|c|c|c|}
\hline Item & \multicolumn{4}{|c|}{ Proportion of barley silage ${ }^{1}$} & $\mathrm{SEM}^{2}$ & \multicolumn{2}{|c|}{ Orthogonal contrasts } \\
\hline $\begin{array}{l}\text { Intake, } \mathrm{g} / \mathrm{d} \\
\text { NAN flow entering the omasal canal, g/d }\end{array}$ & 495 & 466 & 468 & 442 & 8.8 & 0.02 & 0.86 \\
\hline Total & 512 & 468 & 495 & 430 & 11.8 & 0.02 & 0.44 \\
\hline Microbial & 324 & 291 & 319 & 272 & 13.4 & 0.12 & 0.64 \\
\hline Nonmicrobial & 187 & 177 & 176 & 158 & 15.3 & 0.30 & 0.77 \\
\hline NAN flow/N intake & 1.04 & 1.01 & 1.06 & 0.97 & 0.033 & 0.38 & 0.48 \\
\hline In the rumen & 0.624 & 0.621 & 0.625 & 0.643 & 0.0317 & 0.72 & 0.77 \\
\hline Total tract & 0.661 & 0.647 & 0.638 & 0.621 & 0.0057 & $<0.01$ & 0.83 \\
\hline $\mathrm{N}$ in urine, $\mathrm{g} / \mathrm{d}$ & 138 & 129 & 129 & 111 & 6.2 & 0.05 & 0.52 \\
\hline $\mathrm{N}$ in feces, $\mathrm{g} / \mathrm{d}$ & 168 & 165 & 170 & 168 & 3.0 & 0.73 & 0.91 \\
\hline
\end{tabular}

${ }^{1}$ Diets consisted of grass silage alone or with $0.20,0.40$, or 0.60 of this replaced by whole crop barley silage (on DM basis).

${ }^{2}$ For the diet of which 0.60 consisted of whole crop barley silage, SEM should be multiplied by 1.29.

${ }^{3} \mathrm{OMTDR}=\mathrm{OM}$ truly digested in the rumen. 
Table 6. Effect of replacing grass silage by whole-crop barley silage on rumen pool size, passage, and digestion kinetics, and the ratio of digestible NDF (dNDF) and indigestible NDF (iNDF) in the rumen and omasal canal

\begin{tabular}{|c|c|c|c|c|c|c|c|}
\hline \multirow[b]{2}{*}{ Item } & \multicolumn{4}{|c|}{ Proportion of barley silage ${ }^{1}$} & \multirow[b]{2}{*}{$\mathrm{SEM}^{2}$} & \multicolumn{2}{|c|}{ Orthogonal contrasts } \\
\hline & 0 & 20 & 40 & 60 & & Linear & Quadratic \\
\hline Digesta, kg & 99.2 & 99.2 & 100.7 & 95.8 & 2.76 & 0.57 & 0.44 \\
\hline Volume, L & 112 & 118 & 116 & 111 & 4.0 & 0.81 & 0.24 \\
\hline $\mathrm{DM}, \mathrm{kg}$ & 13.6 & 14.4 & 14.5 & 13.5 & 0.31 & 0.88 & 0.04 \\
\hline $\mathrm{OM}, \mathrm{kg}$ & 12.4 & 13.2 & 13.2 & 12.3 & 0.29 & 0.84 & 0.04 \\
\hline NDF, kg & 8.63 & 9.13 & 9.33 & 8.54 & 0.211 & 0.96 & 0.04 \\
\hline iNDF,${ }^{3} \mathrm{~kg}$ & 2.85 & 3.47 & 3.83 & 4.08 & 0.140 & $<0.01$ & 0.28 \\
\hline $\mathrm{dNDF}, \mathrm{kg}$ & 5.77 & 5.67 & 5.50 & 4.47 & 0.128 & $<0.01$ & 0.02 \\
\hline iNDF $k_{\mathrm{p}}, 4$, $1 / \mathrm{h}$ & 0.0294 & 0.0255 & 0.0256 & 0.0259 & 0.00122 & 0.17 & 0.18 \\
\hline $\begin{array}{l}\mathrm{dNDF} \mathrm{k}_{\mathrm{d}}, 1 / \mathrm{h} \\
\mathrm{dNDF} / \mathrm{N} D \mathrm{~F} \text { in }\end{array}$ & 0.0356 & 0.0338 & 0.0325 & 0.0325 & 0.00117 & 0.14 & 0.50 \\
\hline Rumen & 2.02 & 1.63 & 1.45 & 1.15 & 0.039 & $<0.01$ & 0.36 \\
\hline Omasal canal & 1.23 & 1.12 & 1.08 & 1.07 & 0.031 & 0.02 & 0.21 \\
\hline
\end{tabular}

${ }^{1}$ Diets consisted of grass silage alone or with $0.20,0.40$, or 0.60 of this replaced by whole crop barley silage (on DM basis).

${ }^{2}$ For the diet of which 0.60 consisted of whole crop barley silage, SEM should be multiplied by 1.29.

${ }^{3}$ iNDF determined by $12-d$ in situ incubation in the rumen.

${ }^{4}$ Passage rate of iNDF from the rumen.

${ }^{5}$ Rate of dNDF digestion in the rumen.

bohydrates. The starch concentration of barley silage in the present study ( $124 \mathrm{~g} / \mathrm{kg}$ of DM) corresponds to that of whole-crop wheat harvested at the early dough stage (Sutton et al., 2002). Inclusion of barley silage in the diet changed the composition of carbohydrates fermented in the rumen such that the amount of NDF digested in the rumen decreased linearly from 4.87 to $3.56 \mathrm{~kg} / \mathrm{d}$, whereas the amount of starch digested increased from 2.36 to $3.35 \mathrm{~kg} / \mathrm{d}$. Inclusion of barley silage in the diet substantially reduced fiber digestibility, whereas starch was completely digested in all diets, such that digestible OM intake was not affected by the type of diet. The high starch digestibility observed in the current study may be attributed to the early stage of the barley silage harvest and the high moisture content of barley grain. Consistent with this hypothesis, Polan et al. (1968) noted that cows fed barley silage harvested at the hard dough stage excreted a large proportion of grain undigested in feces. In contrast, no such observations were reported when barley silage was harvested at the boot or milk dough stages.

\section{Intake and Fiber Digestibility}

In ruminants, the concentration of digestible nutrients in feed is primarily determined by fiber concentration and digestibility because the true digestibility of cell solubles is often complete (Nousiainen et al., 2003). With small-grain cereals, incomplete cell soluble digestibility is attributed to the presence of unprocessed grain (Sutton et al., 1997; Jackson et al., 2004). The quantity of nutrients absorbed from the gastrointestinal tract is mainly dictated by DMI and OM digestibility. Several studies have indicated that partial replacement of grass silage with whole-crop small grain cereals increases DMI (Phipps et al., 1995; Abdalla et al., 1999; Sinclair et al., 2003). This effect could be explained by decreases in fiber intake with concomitant increases in grain intake or by changes in passage and digestion kinetics of cell walls.

The effects of barley silage on DMI have been inconsistent, which is probably due to inherent variation in the quality of experimental forages. Similar proportions of barley silage in the diet as in the current study had no effect on DMI in a production study with dairy cows (Jaakkola et al., 2001). Several studies have reported increases in DMI due to partial replacement of grass silage with whole-crop wheat (Sutton et al., 1997; Abdalla et al., 1999; Sinclair et al., 2003). The beneficial effects of whole-crop silage on DMI may not be linear because a mixture of forages has resulted in higher DMI than either forage fed alone (Sutton et al., 1997; Jaakkola et al., 2001). By contrast, Khorasani et al. $(1993,1996)$ noted reductions in DMI when barley silage replaced alfalfa silage in dairy cow diets. Intake reductions were attributed to the high NDF concentration and slow digestion rate of cereal whole-crop silages (Khorasani et al. 1996).

In general, the effects of replacing grass silage with barley silage on diet intake and digestibility will depend on the quality of each forage. The nutritional quality of grass silage is primarily determined by the stage of maturity (Rinne et al., 1999) and the extent of fermentation (Huhtanen et al., 2002; Shingfield et al., 2002). 
The nutritional quality of barley silage is influenced by the stage of harvest, cutting height, plant variety, and growing conditions that affect the chemical composition and relative proportions of crop components, grain, and straw (Kennelly and Weinberg, 2003).

Increases in grass silage maturity from early to late growth stage decreased OM digestibility from 0.79 to 0.73 and NDF digestibility from 0.73 to 0.66 . These effects were associated with consistent decreases in DMI and milk yield (Rinne et al., 1999). With smallgrain cereal silages, the effects of silage composition and digestibility on DMI have been less consistent. Increasing whole-crop wheat starch digestibility by mechanical processing or decreasing the NDF concentration by increasing the cutting height were reflected in DMI such that cows maintained their digestible OM intake and milk yield irrespective of wheat silage quality (Jackson et al., 2004). Large differences in OM ( 0.76 vs. 0.65$)$ and NDF digestibility ( 0.70 vs. 0.45$)$ were observed between whole-crop barley silages harvested at boot and early dough stages in studies with heifers (Acosta et al., 1991). In spite of large differences in digestibility, the different harvest stages had only minor effects on DMI and milk yield in a subsequent dairy cow study (Acosta et al., 1991). It seems that whole crop cereals allow cows more flexibility in regulating their intake in relation to energy demand than grass silage does.

Fiber digestibility is dependent on the intrinsic characteristics of the feed that determine the rate and extent of digestion that can be attained under optimal conditions. Grass silage iNDF concentration typically falls within a range of 17 to $167 \mathrm{~g} / \mathrm{kg}$ of $\mathrm{DM}$, which corresponds to a range of 610 to $840 \mathrm{~g} / \mathrm{kg}$ of DM of in vivo OM digestibility in sheep fed at maintenance level (Nousiainen et al., 2004). In the present study, grass silage was only of moderate digestibility as indicated by an iNDF concentration $(97 \mathrm{~g} / \mathrm{kg}$ of $\mathrm{DM})$ that was higher than the mean of grass silage samples collected from commercial Finnish dairy farms $(79 \mathrm{~g} / \mathrm{kg}$ of DM; Nousiainen et al., 2004). Therefore, responses observed in the current study represent replacement of moderate quality grass silage with whole-crop barley silage harvested at early dough stage.

\section{Digestion and Passage Kinetics}

The rumen pool sizes determined in the current study may have been slightly overestimated because the rumen evacuations were performed only $3 \mathrm{~h}$ after the morning feeding. The estimates of mean retention time of iNDF in the rumen were $34 \mathrm{~h}$ on the grass silage diet and $39 \mathrm{~h}$ on the diets containing barley silage. The mean retention time based on marker passage kinetics was $39 \mathrm{~h}$ in cows consuming $23.7 \mathrm{~kg} / \mathrm{d}$ of grass silagebased diet DM (Ahvenjärvi et al., 2004). However, it is unlikely that the limitations in the sampling protocol would have compromised the dietary effects currently presented. Decreases in ruminal and total tract NDF digestibility after inclusion of barley silage in the diet were attributed to smaller dNDF pool size in the rumen because the effects on dNDF digestion rate were small. The effects on dNDF pool size were partly explained by lower dNDF intake, but the ruminal digestibility of dNDF gradually decreased with the level of barley silage indicating that the $\mathrm{dNDF}$ pool size decreased more than this effect could account for. In spite of decreases in dNDF intake with increasing levels of barley silage, the flow of dNDF entering the omasal canal was not affected by the diet. This observation suggests that inclusion of barley silage altered the passage kinetics of rumen particulate matter without affecting the passage rate of iNDF. Within the constraints of limited rumen capacity, selective retention of highly digestible particulate matter increases dNDF pool size and digestibility in the rumen compared with nonselective passage. Decreases in the ratio of dNDF and iNDF concentrations in digesta flowing out of the rumen compared with the rumen pools is an indication of selective passage of particulate matter from the rumen. Examination of this ratio in the rumen and digesta entering the omasal canal indicated that the differences between these sites gradually decreased with increasing levels of barley silage. These observations suggest that whole-crop barley silage particles were released from the nonescapable pool to the escapable particle pool at a higher rate compared with grass silage.

The decreases in dNDF ruminal digestibility were associated with a trend $(P=0.10)$ toward a higher fractional proportion of dNDF being digested postruminally. Consistent with the current observations, inclusion of whole-crop wheat in grass silage diets caused a shift in the site of fiber digestion from the rumen to the intestines (Abdalla et al., 1999). In the current study, postruminal digestion compartments comprise the omasum and the intestines. Previous evidence has suggested that the omasum has a greater role in fiber digestion than the intestines (Ahvenjärvi et al., 2000, 2001). However, only small compensation for lower ruminal dNDF digestibility occurred at these sites because the decreases in total tract $\mathrm{dNDF}$ digestibility were similar to those in the rumen.

\section{Rumen Fermentation}

The effects of barley silage on the VFA pattern currently observed are mainly attributed to the changes in composition of ruminally fermented carbohydrates. 
The rumen fermentation pattern in the grass silage diet was characteristic for cows receiving restrictively fermented grass silage-based diets (Huhtanen, 1998). Increasing the proportion of barley-based concentrate in the diet has typically decreased the molar proportion of acetate and increased that of butyrate, whereas the molar proportion of propionate has been little affected (Huhtanen, 1987). Changes in silage composition due to the effects of stage of maturity have had larger effects on rumen fermentation than those achieved with concentrate supplementation (Rinne et al., 1997). In agreement with the current findings, the molar proportions of acetate and butyrate were lower and that of propionate was higher in cows consuming small grain cereal silages than in cows consuming alfalfa silage (Khorasani et al., 1996).

\section{Nitrogen}

Because barley silage had a lower $\mathrm{N}$ concentration than grass silage, inclusion of barley linearly decreased the $\mathrm{N}$ concentration of the diet and the $\mathrm{N}$ intake. The amount of fecal DM output increased linearly with the level of barley silage, but this was associated with concomitant linear decreases in fecal $\mathrm{N}$ concentration. As a result, the fecal $\mathrm{N}$ output remained consistent in all diets. Decreases in $\mathrm{N}$ intake were associated with decreases in the ruminal ammonia- $\mathrm{N}$ concentrations and the amount of $\mathrm{N}$ excreted in urine. The daily averages of ruminal ammonia concentrations were lower than the suggested minimum levels for optimum fiber digestion $(5.7 \mathrm{mmol} / \mathrm{L}$; Hoover, 1986). However, despite decreases in ruminal ammonia-N levels in diets with barley silage inclusion, only small decreases were noted in the rate of $\mathrm{dNDF}$ digestion. Consistent with low ruminal ammonia-N concentrations, average NAN flow exceeded $\mathrm{N}$ intake, such that microbial $\mathrm{N}$ synthesis was higher than $\mathrm{N}$ supply from protein degraded in the rumen. Decreases in NAN flow entering the omasal canal with increasing barley inclusion were mainly explained by decreases in microbial $\mathrm{N}$ flow. However, no differences were detected between diets in the efficiency of microbial $\mathrm{N}$ synthesis.

\section{Milk Production}

An increase in the proportion of barley silage in the diet decreased milk yield. Lower performance could be explained by lower NAN flow entering the omasal canal. In addition, differences in digestible carbohydrate composition may have contributed to the effects on milk yield. Responses to additional ME intake from concentrate supplementation of grass silage diets have been shown to be lower than responses to additional $\mathrm{ME}$ from improved forage digestibility (Huhtanen, 1998).
In the case of small-grain cereal silages, the relationship between silage composition and milk production has been less consistent than what has been observed with grass silage. Jackson et al. (2004) reported similar milk yield for cows receiving 4 whole-crop wheat silages that differed in terms of processing at harvest and cutting height and ensuing effects on starch digestibility and relative proportions of grain and straw in the forage.

\section{CONCLUSIONS}

Replacing grass silage with whole-crop barley silage decreased $\mathrm{OM}$, and fiber digestibility, $\mathrm{N}$ intake, and NAN flow entering the omasal canal. Decreases in NDF digestibility were related to higher indigestible NDF concentration of barley silage compared with that of grass silage and to a smaller dNDF pool size in the rumen. Digestible OM intake was not affected by the diet because increases in starch intake with barley silage compensated for reductions in OM digestibility. However, the effects of barley silage on digestible carbohydrate composition of the diet and NAN flow resulted in linear decreases in milk yield.

\section{REFERENCES}

Abdalla, A. L., J. D. Sutton, R. H. Phipps, and D. J. Humphries. 1999. Digestion in the rumen of lactating dairy cows given mixtures of urea-treated whole-crop wheat and grass silage. Anim. Sci. 69:203-212.

Acosta, Y. M., C. C. Stallings, C. E. Polan, and C. N. Miller. 1991. Evaluation of barley silage harvested at boot and soft dough stages. J. Dairy Sci. 74:167-176.

Ahvenjärvi, S., B. Skiba, and P. Huhtanen. 2001. Effect of heterogeneous digesta chemical composition on the accuracy of measurements of fiber flow in dairy cows. J. Anim. Sci. 79:1611-1620.

Ahvenjärvi, S., A. Vanhatalo, A. N. Hristov, and P. Huhtanen. 2004. Passage kinetics of internal and external markers in lactating dairy cows. J. Anim. Feed Sci. 13:19-22.

Ahvenjärvi, S., A. Vanhatalo, P. Huhtanen, and T. Varvikko. 2000. Determination of reticulo-rumen and whole-stomach digestion in lactating cows by omasal canal or duodenal sampling. Br. J. Nutr. 83:67-77.

Bach Knudsen, K. E., P. Åman, and P. O. Eggum. 1987. Nutritive value of Danish grown barley varieties. I. Carbohydrates and other major constituents. J. Cereal Sci. 6:173-186.

France, J., and R. C. Siddons. 1986. Determination of digesta flow by continuous marker infusion. J. Theor. Biol. 121:105-119.

Gill, M., P. H. Robinson, and J. J. Kennelly. 1999. Diurnal patterns in rumen volume and composition of digesta flowing into the duodenum. Anim. Sci. 69:237-249.

Hoover, W. H. 1986. Chemical factors involved in ruminal fiber digestion. J. Dairy Sci. 69:2755-2766.

Huhtanen, P. 1987. The effects of carbohydrate supplements on the utilization of grass silage diets. Academic dissertation, University of Helsinki, Finland.

Huhtanen, P. 1998. Supply of nutrients and productive responses in dairy cows given diets based on restrictively fermented silage. Agric. Food Sci. Finl. 7:219-250.

Huhtanen, P. J., R. Blauwiekel, and I. Saastamoinen. 1998. Effects of intraruminal infusions of propionate and butyrate with two different protein supplements on milk production and blood me- 
tabolites in dairy cows receiving grass silage-based diets. J. Sci. Food Agric. 77:213-222.

Huhtanen, P., P. G. Brotz, and L. D. Satter. 1997. Omasal sampling technique for assessing fermentative digestion in the forestomach of dairy cows. J. Anim. Sci. 75:1380-1392.

Huhtanen, P., H. Khalili, J. I. Nousiainen, M. Rinne, S. Jaakkola, T. Heikkilä, and J. Nousiainen. 2002. Prediction of the relative intake potential of grass silage by dairy cows. Livest. Prod. Sci. 73:111-130.

Huida, L., H. Väätäinen, and M. Lampila. 1986. Comparison of dry matter contents in grass silages as determined by oven drying and gas chromatographic water analysis. Ann. Agric. Fenn. 25:215-230.

Jaakkola, S., E. Saarisalo, and T. Heikkilä. 2001. Whole-crop barley silage for dairy cows. Pages 69-74 in Proc. Seminar no. 326, Production and utilisation of silage. The Nordic Association of Agr. Scientists (NJF), Lillehammer, Norway.

Jackson, M. A., R. J. Readman, J. A. Huntington, and L. A. Sinclair. 2004. The effects of processing at harvest and cutting height of urea-treated whole-crop wheat on performance and digestibility in dairy cows. Anim. Sci. 78:467-476.

Kennelly, J. J., and Z. G. Weinberg. 2003. Small grain silage. Pages 749-779 in Silage Science and Technology. D. R. Buxton, R. E. Muck, and J. H. Morrison, ed. Am. Soc. Agron., Inc., Crop Sci. Soc. Am., Inc., Soil Sci. Soc. Am., Inc., Madison, WI.

Khorasani, G. R., E. K. Okine, and J. J. Kennelly. 1996. Forage source alters nutrient supply to the intestine without influencing milk yield. J. Dairy Sci. 79:862-872.

Khorasani, G. R., E. K. Okine, J. J. Kennelly, and J. H. Helm. 1993. Effect of whole crop cereal grain silage substituted for alfalfa silage on performance of lactating dairy cows. J. Dairy Sci. 76:3536-3546.

Littell, R. C., P. R. Henry, and C. B. Ammerman. 1998. Statistical analysis of repeated measures data using SAS procedures. J. Anim. Sci. 76:1216-1231.

McCullough, H. 1967. The determination of ammonia in whole blood by direct colorimetric method. Clin. Chim. Acta 17:297-304.

National Research Council. 2001. Nutrient Requirements of Dairy Cattle. 7th rev. ed. Natl. Acad. Sci., Washington, DC.

Nousiainen, J., S. Ahvenjärvi, M. Rinne, M. Hellämäki, and P. Huhtanen. 2004. Prediction of indigestible cell wall fraction of grass silage by near infrared reflectance spectroscopy. Anim. Feed Sci. Technol. 115:295-311.

Nousiainen, J., M. Rinne, M. Hellämäki, and P. Huhtanen. 2003. Prediction of the digestibility of the primary growth of grass silages harvested at different stages of maturity from chemical composition and pepsin-cellulase solubility. Anim. Feed Sci. Technol. 103:97-111.

Phipps, R. H., J. D. Sutton, and B. A. Jones. 1995. Forage mixtures for dairy cows: the effect on dry-matter intake and milk production of incorporating either fermented or urea-treated whole-crop wheat, brewer's grains, fodder beet or maize silage into diets based on grass silage. Anim. Sci. 61:491-496.
Polan, C. E., T. M. Starling, J. T. Huber, C. N. Miller, and R. A. Sandy. 1968. Yields, compositions, and nutritive evaluation of barley silages at three stages of maturity for lactating cows. J. Dairy Sci. 51:1801-1805.

Rinne, M., S. Jaakkola, and P. Huhtanen. 1997. Grass maturity effects on cattle fed silage-based diets. 1 . Organic matter digestion, rumen fermentation and nitrogen utilization. Anim. Feed Sci. Technol. 67:1-17.

Rinne, M., S. Jaakkola, K. Kaustell, T. Heikkilä, and P. Huhtanen. 1999. Silages harvested at different stages of grass growth vs. concentrate foods as energy and protein sources in milk production. Anim. Sci. 69:251-263.

Shingfield, K. J., S. Jaakkola, and P. Huhtanen. 2002. Effect of forage conservation method, concentrate level and propylene glycol on intake, feeding behaviour and milk production of dairy cows. Anim. Sci. 74:383-397.

Sinclair, L. A., R. G. Wilkinson, and D. M. R. Ferguson. 2003. Effects of crop maturity and cutting height on the nutritive value of fermented whole crop wheat and milk production in dairy cows. Livest. Prod. Sci. 81:257-269.

Sutton, J. D., A. L. Abdalla, R. H. Phipps, S. B. Cammell, and D. J. Humphries. 1997. The effect of the replacement of grass silage by increasing proportions of urea-treated whole-crop wheat on food intake and apparent digestibility and milk production by dairy cows. Anim. Sci. 65:343-351.

Sutton, J. D., S. B. Cammell, D. E. Beever, D. J. Humphries, and R. H. Phipps. 1998. Energy and nitrogen balance of lactating dairy cows given mixtures of urea-treated whole-crop wheat and grass silage. Anim. Sci. 67:203-212.

Sutton, J. D., R. H. Phipps, E. R. Deaville, A. K. Jones, and D. J. Humphries. 2002. Whole-crop wheat for dairy cows: Effects of crop maturity, a silage inoculant and an enzyme added before feeding on food intake and digestibility and milk production. Anim. Sci. 74:307-318.

Udén, P., P. E. Colucci, and P. J. Van Soest. 1980. Investigation of chromium, cerium and cobalt as markers in digesta. Rate of passage studies. J. Sci. Food Agric. 31:625-632.

Van Soest, P. J., J. B. Robertson, and B. A. Lewis. 1991. Methods for dietary fiber, neutral detergent fiber and nonstarch polysaccharides in relation to animal nutrition. J. Dairy Sci. 74:35833597.

Vanhatalo, A., S. Jaakkola, A. Rauramaa, J. Nousiainen, and A. Taommila. 1999. Additives in ensiling whole crop barley. Pages 121-122 in Proc. XIIth Int. Silage Conf., Silage production in relation to animal performance, animal health, meat and milk quality. Swedish University of Agricultural Sciences, Uppsala, Sweden.

Williams, C. H., D. David, and O. Iismaa. 1962. The determination of chromic oxide in faeces samples by atomic absorption spectrometry. J. Agric. Sci. 59:381-385.

Zinn, R. A., and F. N. Owens. 1986. A rapid procedure for purine measurement and its use for estimating net ruminal protein synthesis. Can. J. Anim. Sci. 66:157-166. 